\title{
The Social Dimensions of Sustainable Development: The Importance of Creating New Partnerships
}

\author{
Opinion
}

Volume 2 Issue 3- 2021

\author{
Author Details \\ Wasif Ali*, Julie Drolet \\ Faculty of Social Work, University of Calgary, Canada
}

*Corresponding author

Wasif Ali, Postdoctoral Associate, Faculty of Social Work, University of Calgary, Canada

Article History

Received: June 19, 2021 Accepted: June 25, 2021 Published: June 29, 2021

\begin{abstract}
Opinion
Internationally, there is emerging global agreement that environmental change is one of the greatest threats to ecosystems, culture, health, and economies of humankind [1]. Climate change and environmental disasters are destabilizing communities across the world [2]. Many professions in the health, sciences, engineering, and social sciences disciplines are concerned with preparing student graduates to address the complex challenges associated with sustainable development. There is an urgent need for collaborative research and partnerships from multiple disciplines to address the critical issues of our times.
\end{abstract}

In 2015, the United Nations and its members adopted the global agenda 'Transforming Our World: The 2030 Agenda for Sustainable Development.' The Sustainable Development Goals (SDGs), which replaced the Millennium Development Goals, promote the inclusive development of all people and communities. The theme 'no one will be left behind' aims to focus attention on vulnerable and marginalized populations with 17 SDG goals and 169 targets [3]. The social and human dimensions are essential features of each SDG, such as water, environment, clean energy, responsible consumption, and sustainable cities; every aspect requires active community participation. Without the acceptance of SDGs by individuals, groups, and communities, it is hard to imagine how the world can achieve a sustainable future [4]. Everyone has a role to play in fostering a more sustainable world.

Contemporary challenges and development priorities with respect to the SDGs accelerated academic debates about sustainability studies. For example, sustainability science has been found to focus on generating and applying knowledge to environmentally sound human development around the world, which requires greater integration of different types of knowledge and ways of knowing [5]. Sustainable development calls for transformation and new thinking, and the integration of social, economic and environmental dimensions [6]. As new interdisciplinary work emerges to address complex challenges, it is critical for the profession of social work to engage with the health, sciences, engineering, and other social science fields to create new knowledge and understanding, and vice versa.

Social work is a profession focused on people within their environments. For many years, people were considered in the context of their social environment. According to Boddy, MacFarlane et al. [7], this focus is reflected in codes of ethics, with a shared mandate to work towards individual wellbeing and social change. The social work literature now considers environmental and eco-social work and green social work approaches, which consider people in their natural and physical environment. Environmental issues are increasingly found in social work research, policy, and practice frameworks in recognition of the importance of ecological justice and the interconnectedness of humans with nature [8].

The profession of social work is particularly concerned with advancing social justice and human rights to foster resilient, inclusive, and sustainable societies. Environmental challenges, diminishing natural resources, large-scale industrial development, rapidly increasing species extinction, ocean acidification, deforestation, pollution, overconsumption, and the exploitation of the natural environment have led to events that disproportionately affect marginalized populations, including Indigenous peoples $[9,10]$. The environmental crises associated with climate change and disasters exacerbate existing socio-economic and cultural inequalities, calling for action to promote environmental justice [11]. The profession of social work is committed to social justice and human rights issues, and this includes environmental justice [12].

Transformative eco-social change, involving the integration of philosophical principles emphasizing holism and interdependence with the natural world, is critical for developing a coherent and ethical approach to addressing ecological and social problems [13]. According to Dylan [14], if social workers are to advocate successfully 
for environments conducive to the general welfare of all people, promote social justice, equitable distribution of resources, and just environmental management, environmental social work scholarship needs to move beyond theorizing and provide illustrative examples of interventions and alternative practices. This will also require new interdisciplinary approaches.

In many professions, field education, or what is referred to as practicum, internship, preceptorship, or work-integrated learning, provides students with an opportunity to develop practice skills and apply their course-based learning in the field. In Canada and internationally, there are increasing challenges associated with providing students with quality field placements to advance their learning for multiple reasons [15]. The Transforming the Field Education Landscape (TFEL) project aims to create training and mentoring opportunities for students, develop and mobilize innovative and promising field education practices, and improve the integration of research and practice in field education. To inform the development of sustainable models of field education, TFEL created a Green Social Work Advisory. The Advisory brings together undergraduate and graduate students in a national study to identify promising and wise practices that can mitigate the challenges and strengthen innovation in field education. Innovative approaches need to be documented, shared, and exchanged.

It is evident from social development reports in many parts of the world that multidisciplinary actions are vital for a sustainable future; in the areas of water and environmental sustainability, the social and technical nexus require innovative governance approaches and solutions [16]. Participatory action research, stakeholder and community engagement, and integrated approaches are prevalent in sustainable development discourses. With the emergence of socio-ecological, socio-institutional, and socio-technical models for sustainable development [17], new interdisciplinary approaches can be adopted to foster creative and multisystemic interventions. With the emerging sustainability debates, the concept of education for sustainable development is evolving across the disciplines [18] For example, SDG 4 advocates "by 2030, ensure that all learners acquire the knowledge and skills needed to promote sustainable development, including, among others, through Education for Sustainable Development and sustainable lifestyles, human rights, gender equality, promotion of a culture of peace and nonviolence, global citizenship and appreciation of cultural diversity and of culture's contribution to sustainable development" [19]. To better address the social dimensions of sustainable development, we call upon the health, sciences, engineering, and social sciences disciplines to engage with the social work profession to better meet the needs of vulnerable groups and communities.

\section{References}

1. Klemmer CL, McNamara KA (2020) Deep ecology and ecofeminism: Social work to address global environmental crisis. Affilia 35(4): 503 515 .

2. Alston M (2015) Social work, climate change and global cooperation International Social Work 58(3): 355-363.

3. Jayasooria, D. (2016). Sustainable development goals and socia work: Opportunities and challenges for social work practice in Malaysia. Journal of Human Rights and Social Work 1(1): 19-29.
4. Pawar M (2017) The need for enhanced community participation. In: J Midgley \& M. Pawar (Eds.). Future directions in social development. New York: Palgrave Macmillan; pp: 79-98.

5. Athayde S, Silva-Lugo J, Schmink M, Kaiabi A, Heckenberger M (2017) Reconnecting art and science for sustainability: Learning from Indigenous knowledge through participatory action-research in the Amazon. Ecology and Society 22(2): 485-488.

6. Drolet J (2020) A new partnership: Transforming the field education landscape: Intersections of research and practice in Canadian social work field education. Field Educator 10(1): 1-18.

7. Boddy J, Macfarlane S, Greenslade L (2018) Social work and the natural environment: Embedding content across curricula. Australian Social Work 71(3): 367-375.

8. Harris C, Boddy J (2017) The natural environment in social work education: A content analysis of Australian social work courses. Australian Social Work 70(3): 337-349.

9. Billiot S, Beltran R, Brown D, Mitchell FM, Fernandez A (2019) Indigenous perspectives for strengthening social responses to global environmental changes: A response to the social work grand challenge on environmental change. Journal of Community Practice 27(3-4): 296-316.

10. Cunsolo A, Landman K (2017) Mourning nature: Hope at the heart of ecological loss and grief. McGill-Queen's University Press.

11. Dominelli L (2014) Promoting environmental justice through green social work practice: A key challenge for practitioners and educators. International Social Work 57(4): 338-345.

12. Drolet J, Ali W, Williams N. Environment and environmental justice. In C Cox \& T Maschi (Eds.). Integrating Human Rights and Social Justice into Social Work Practice. Routledge.

13. Boetto H (2019) Advancing transformative eco-social change: Shifting from modernist to holistic foundations. Australian Social Work 72(2): 139-151.

14. Dylan A (2015) Ecology and social justice: Teaching environmental justice in a rural context. Contemporary Rural Social Work 7(1): 26-38.

15. Drolet J, Todd S (2020) Community practice and social development themes and implications. In: S Todd \& J Drolet (Eds.). Community practice and social development in social work. pp. 457-472.

16. Hülsmann S, Ardakanian R (2018) The nexus approach as tool for achieving SDGs: Trends and needs. In: S Hulsmann, R Ardakanian (Eds.). Managing water, soil and waste resources to achieve sustainable development goals. pp. 1-9.

17. Loorbach D, Frantzeskaki N, Avelino F (2017) Sustainability transitions research: Transforming science and practice for societal change. Annual Review of Environment and Resources 42: 599-626.

18. Weiland S, Hickmann T, Lederer M, Marquardt J, Schwindenhammer S (2021) The 2030 Agenda for sustainable development: Transformative change through the Sustainable Development Goals. Politics and Governance 9(1): 90-95.

19. United Nations (2015) Transforming our world: The 2030 agenda for sustainable development. New York: United Nations; Department of Economic and Social Affairs. 